\title{
Inhibitors of the hepatitis C virus RNA-dependent RNA polymerase
}

\author{
Stefania Colarusso, Barbara Attenni, Salvatore Avolio, Savina Malancona, Steven Harper, \\ Sergio Altamura, Uwe Koch and Frank Narjes*
}

Istituto Di Ricerche Di Biologia Molecolare, P. Angeletti S.p.A. (Merck Research Laboratories, Rome), Via Pontina Km 30,600, 00040 Pomezia, Italy

E-mail: frank_narjes@merck.com

\begin{abstract}
Infections caused by Hepatitis C Virus (HCV) are a significant world health problem for which novel therapies are in urgent demand. The polymerase of HCV is responsible for the replication of viral RNA. We recently disclosed diketoacids $\mathbf{1}$ and dihydroxypyrimidine carboxylates $\mathbf{3}$ as novel, reversible inhibitors of the HCV NS5B polymerase. We report here the further development of $\mathbf{3}$ into the more potent 5,6-dihydroxy-2-(2-thienyl)pyrimidine-4-carboxylic acids. The structure activity relationship of these inhibitors is discussed in the context of their physicochemical properties, supporting the proposed binding model, which involves pyrophosphate like chelation of the active site Mg-ions. We also report on the discovery and synthesis of two related scaffolds, the $N 1$-substituted pyrimidones and pyridine- $N$-oxides.
\end{abstract}

Keywords: Hepatitis C virus, NS5B polymerase, pyrimidines, N1-substituted pyrimidones, pyridine- $N$-oxides

\section{Contents}

Introduction

1. 5,6-Dihydroxypyrimidine-4-carboxylic acids

1.1. SAR in the 2-position

1.2. 2-(2-Thienyl)-5,6-dihydroxy-4-carboxy-pyrimidines

2. Investigation of the dihydroxypyrimidine core

2.1. N1-substituted pyrimidones

2.2. Pyridine- $N$-oxides

Conclusions 


\section{Introduction}

Hepatitis C Virus (HCV) infection constitutes a global health problem, which affects more than 170 million individuals. ${ }^{1,2}$ If untreated, more than $60 \%$ of these individuals will develop chronic liver disease, which in $15-20 \%$ of the cases can lead to chronic hepatitis, liver cirrhosis and even hepatocellular carcinoma. ${ }^{3}$ The current therapy, a combination of pegylated $\alpha$-interferon (IFN) and ribavirin, is of limited efficacy and poorly tolerated. ${ }^{4}$ This has stimulated intense research programs in the pharmaceutical industry to find a broadly effective antiviral therapy. By analogy to HIV research, most efforts to develop antiviral agents for HCV have focused on inhibition of the essential viral enzymes. ${ }^{5-7}$

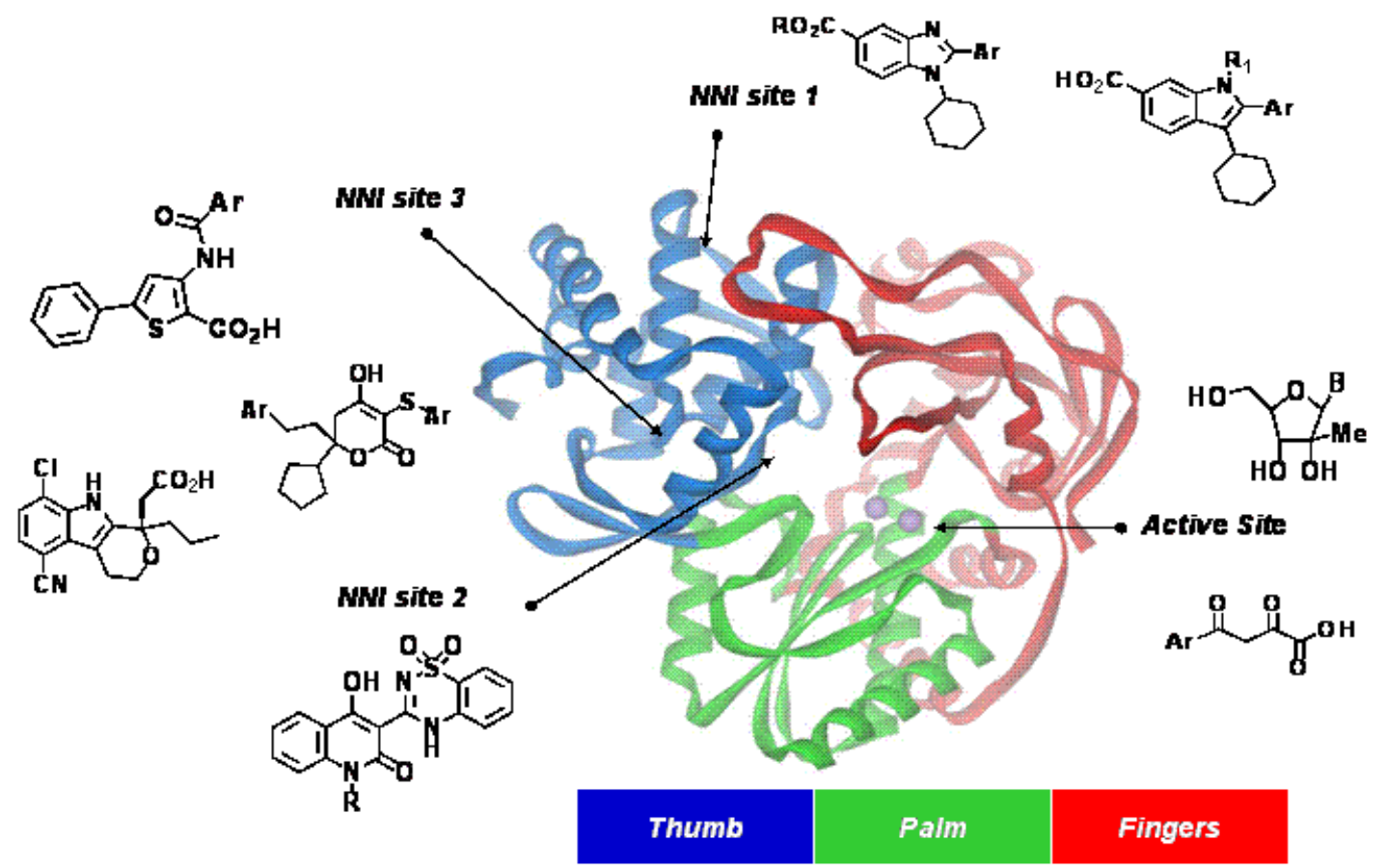

Figure 1. Structure of the HCV NS5B RNA polymerase with structures of selected inhibitors and their respective binding sites

HCV is a small, enveloped virus, belonging to the Flaviviridae, a family of positive strand RNA viruses. Its genome is approximately 9600 nucleotides in length and encodes a single polyprotein of about 3000 amino acids. This polyprotein undergoes maturational processing in the cytoplasm or in the endoplasmic reticulum of infected cells to generate structural and nonstructural (NS) viral proteins. ${ }^{8}$ Among the NS proteins are two viral enzymes, which are crucial for viral replication and consequently were selected as potential targets for antiviral therapy. The NS3 protease-helicase processes the viral polyprotein downstream of it and liberates the NS5B RNA dependent RNA polymerase (NS5B RdRp), the catalytic core of the HCV replication machinery. ${ }^{9}$ 
The NS5B RdRP has been characterized by biochemical methods and by X-ray crystallography. It adopts a tertiary structure which resembles a right hand, a motif common to most nucleotide polymerizing enzymes. The catalytic activity of the enzyme is mediated by two magnesium ions in the active site, which serve to activate the 3'-OH of the elongating RNA and position the incoming nucleotide-triphosphate for nucleophilic attack. ${ }^{10-12}$

NS5B is not expressed in uninfected cells, and due to its unique features presents an attractive target for the development of safe antiviral drugs. Several laboratories, including ours, $^{13}$ have disclosed non-nucleoside (NNI) inhibitors. These include a variety of heterocyclic systems, which have been shown to bind to three distinct sites on the polymerase (Figure 1). ${ }^{14,15}$

Apart from allosteric inhibitors, classical chain-terminating nucleoside (substrate) analogs, ${ }^{16}$ and pyrophosphate (product) analogs like diketoacids $\mathbf{1}$ have been described (Figure 1, 2). ${ }^{17}$ The latter were found by screening of the Merck compound collection. Diketoacids have been proposed to inhibit HIV-integrase by a mechanism involving chelation of active site magnesium ions. ${ }^{18}$ Recently we reported that 1 inhibits selectively the NS5B RdRP elongation step. ${ }^{17}$ Kinetic experiments indicated that $\mathbf{1}$ and Foscarnet, ${ }^{19}$ a known pyrophosphate mimic and an approved antiviral drug, interact at a common binding site.<smiles></smiles>

$1 \quad \mathrm{IC}_{50} 5.7 \mu \mathrm{M}$<smiles>CCOC(=O)c1cc(=O)c(O)c(C(=O)O)o1</smiles>

$2 \mathrm{C}_{50} 2.3 \mu \mathrm{M}$<smiles>O=C(O)c1nc(-c2ccccc2)nc(O)c1O</smiles>

$3 \quad \mathrm{C}_{50} 30 \mu \mathrm{M}$

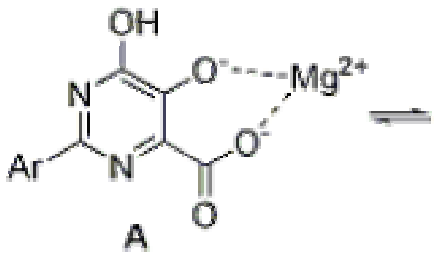

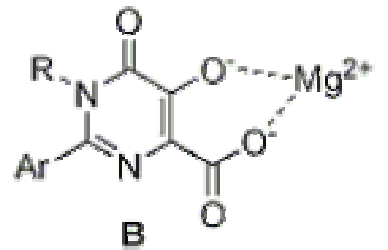

\section{Figure 2}

While structures like 1 could be converted to potent inhibitors of the NS5B polymerase by substitution on the phenyl ring, ${ }^{17}$ the inherent reactivity of the diketoacid moiety presented a problem for the further development of these compounds as drug candidates.

As second hit from random screening was the meconic acid derivative 2 (Figure 2). This compound was more potent than $\mathbf{1}$, but the chemical instability prevented further exploration of this scaffold. ${ }^{20}$ In the search for chemically and biologically stable diketoacid replacements 2aryl-5,6-dihydroxy-pyrimidine-4-carboxylic acid $\mathbf{3}$ was identified. ${ }^{21}$ Similar to diketoacids, 
binding of 3 is mediated by divalent cations such as $\mathrm{Mg}^{2+}$ or $\mathrm{Mn}^{2+}$. Furthermore, 3 was shown to be competitive with diketoacids, indicating that both interact at a common binding site, and suggesting that the dihydroxy acid moiety of $\mathbf{3}$ chelates the active site metal, as shown for structure $\mathbf{A}$ in its bis-anionic form. Dihydroxypyrimidine A can also exist in the tautomeric pyrimidone form $\mathbf{B}$ (Figure 2), which in principle is also capable of magnesium ion chelation. Presently, it is not known whether $\mathbf{A}$ or $\mathbf{B}$ or a mixture of them is responsible for the observed inhibition of NS5B RdRP, or if a bis- or monoanion is the active species. That pyrimidone $\mathbf{B}$ is an inhibitor was shown by $N$-methylation $(\mathrm{R}=\mathrm{Me})$ which gave an equally active pyrimidone. ${ }^{22}$

\section{5,6-Dihydroxypyrimidine-4-carboxylic acids}

\subsection{SAR in the 2-position}

With respect to the diketoacid $\mathbf{1}$ the pyrimidine $\mathbf{3}$ is about 5 -fold less active. In an attempt to improve the potency we successfully introduced side-chains onto the phenyl group of $3,{ }^{23,24}$ and also investigated more broadly the SAR of the substituent in the 2-position of 3 . These derivatives were prepared using the published method by Culbertson (Scheme 1). ${ }^{25}$
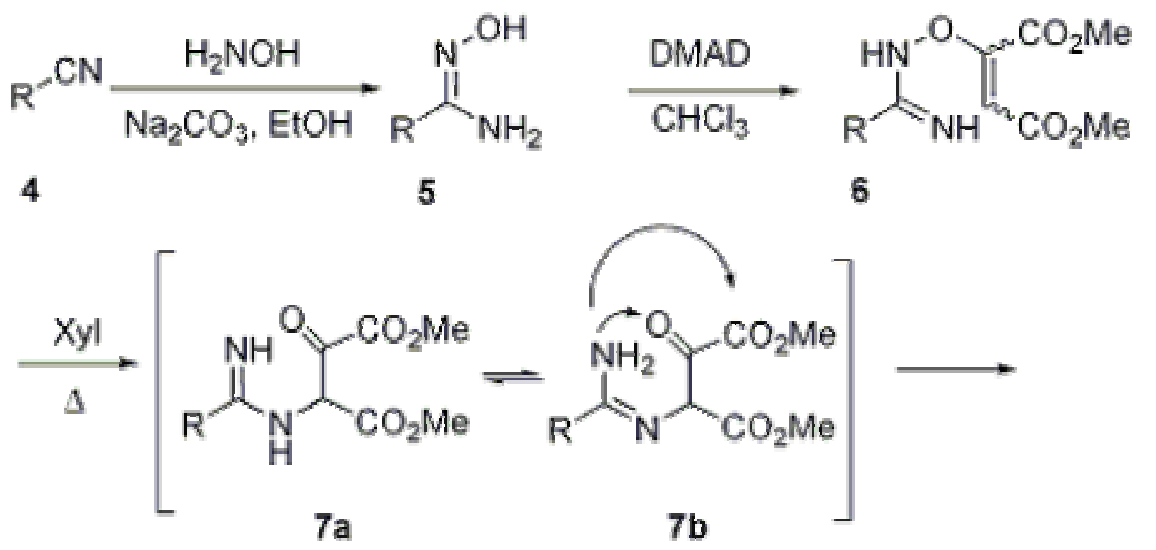<smiles>[R]c1nc(O)c(O)c(C(=O)OC)n1</smiles>

8<smiles>[R]c1nc(O)c(O)c(C(=O)O)n1</smiles><smiles>[R]c1nc(C(=O)OC)c(C(=O)OC)[nH]1</smiles>

17

Scheme 1. Synthesis of 2-substituted 4,5-dihydroxy-pyrimidine-4-carboxylic acids

Amidoximes 5, obtained from nitriles 4, were reacted with dimethylacetylene dicarboxylate (DMAD) to yield the Michael-adducts $\mathbf{6}$ as a mixture of geometrical isomers. Heating these in refluxing xylene gave the desired pyrimidine methyl esters $\mathbf{8}$ in yields ranging 
from 3-65\%, which after hydrolysis with sodium hydroxide gave the final products. Imidazoles 17 were observed in several cases in the LC-MS trace of the crude mixtures. Mechanistically, it is assumed that conversion of $\mathbf{6}$ to $\mathbf{8}$ follows a Claisen-type rearrangement via intermediate 7a, which after tautomerization to $\mathbf{7 b}$ could cyclize onto the ketone to give imidazoles or onto one ester group to yield pyrimidine esters. ${ }^{25}$

A wide variety of compounds were prepared and some of the more interesting analogs are presented in Table $1{ }^{26}$ As the results show, an aryl group directly attached to the 2-position is clearly required for activity, since substituents such as cyclohexyl $\left(\mathbf{9}, \mathrm{IC}_{50}>50 \mu \mathrm{M}\right)$, benzyl (10, IC $\left._{50}>50 \mu \mathrm{M}\right)$ or 3-piperidinyl $\left(\mathbf{1 1}, \mathrm{IC}_{50}>50 \mu \mathrm{M}\right)$ were essentially inactive with respect to 3 . Preferred are 5-membered aromatic heterocycles such as a thiophene (13, $\left.\mathrm{IC}_{50} 2.6 \mu \mathrm{M}\right)$, a furan $\left(14, \mathrm{IC}_{50} 2.9 \mu \mathrm{M}\right)$, or a thiazole $\left(15, \mathrm{IC}_{50} 0.76 \mu \mathrm{M}\right)$, the latter being one of the most active compounds.

The electron-withdrawing nitro group in the 3-position of the thiophene led to another gain in potency, making 16 equipotent to thiazole 15. For these pyrimidines we observed the dependence of the $\mathrm{IC}_{50}$ from the metal ion used in the assay (Table 1), as has been observed in the ketoacid series. This set of results indicated that an electron-withdrawing effect, going from thiophene to the more electro-withdrawing thiazole or nitrothiophene seems to be beneficial for potency, possibly by influencing the $\mathrm{p} K_{\mathrm{a}}$ of the 5-hydroxy group. We assume that this group, together with the acid is involved in chelation of an active site Magnesium ion (see Figure 2), and changes in its $\mathrm{p} K_{\mathrm{a}}$ will influence its chelating capabilities. Determination of the apparent $\mathrm{p} K_{\mathrm{a}}$ -value of the hydroxyl group supports this hypothesis (Table 1$){ }^{26}$

The $\mathrm{p} K_{\mathrm{a}}$ of the phenolic hydroxyl group of all compounds with low micromolar activity is close to seven with inhibition being measured at $\mathrm{pH}$ 7.4. Thus the $\mathrm{pH}$ is close to the inflection point of the $\mathrm{pH}$-dependent dissociation curve and consequently small variations of the $\mathrm{p} K_{\mathrm{a}}$ can significantly change the ratio of the mono- and bis-anionic form under the assay conditions. Depending on which protonation state corresponds to the bio-active form this influences the measured inhibition. From the results presented in Table 1 it becomes clear that generally a more electron-withdrawing substituent in position 2 of the pyrimidine lowers the $\mathrm{p} K_{\mathrm{a}}$ of the 5-hydroxy group.

The most active compounds, thiazole 15 and nitrothiophene 16 also have the lowest $\mathrm{p} K_{\mathrm{a}}$ value. This means that decreasing $\mathrm{p} K_{\mathrm{a}}$ increases the amount of the bis-anionic form under our assay condition ( $\mathrm{pH} 7.4)$.

To test whether an increase in the amount of the doubly deprotonated species leads to an increase in potency the $\mathrm{IC}_{50}$ of the same compound was measured at different $\mathrm{pH}$ values. We

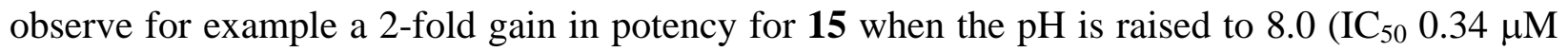
instead of $0.76 \mu \mathrm{M}$ ), and a drop of 2-3-fold at $\mathrm{pH} 7.0\left(\mathrm{IC}_{50} 1.9 \mu \mathrm{M}\right)$. Taking together these results provide evidence for the hypothesis that the doubly deprotonated pyrimidine A (Figure 2) is the bioactive species. Possibly this is due to its better capability to chelate Mg-ions. 
Table 1. Inhibition of NS5B RdRP by 2-substituted dihydroxypyrimidines 3, 9-16

\begin{tabular}{|c|c|c|c|c|}
\hline No. & $\mathrm{R}$ & $\begin{array}{c}\mathrm{IC}_{50}(\mu \mathrm{M}) \\
\mathrm{Mg}^{2+}\end{array}$ & $\begin{array}{c}\mathrm{IC}_{50}(\mu \mathrm{M}) \\
\mathrm{Mn}^{2+}\end{array}$ & $\mathrm{p} K_{\mathrm{a}}$ \\
\hline 3 & & 30 & 2.3 & 8.6 \\
\hline 9 & & $>50$ & & 8.7 \\
\hline 10 & & $>50$ & & - \\
\hline 11 & & $>50$ & & - \\
\hline 12 & & 5.3 & & 7.3 \\
\hline 13 & & 2.6 & 0.24 & 7.7 \\
\hline 14 & & 2.9 & 0.24 & 7.4 \\
\hline 15 & & 0.76 & 0.21 & 6.9 \\
\hline 16 & & 0.68 & 0.07 & 6.9 \\
\hline
\end{tabular}




\subsection{2-(2-Thienyl)-5,6-dihydroxy-4-carboxy-pyrimidines}

Further SAR around the thiophene $\mathbf{1 3}$ established that only substitution of the 3-position was tolerated. A library of around 200 compounds was prepared using the readily available amine $\mathbf{2 1}$, which was reacted with a wide variety of acylating agents (Scheme 2) to give ureas, amides and carbamates. $^{26}$

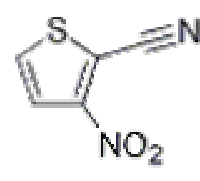

18

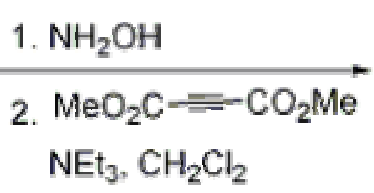

$83 \%$<smiles>CC(=O)C=C(ONC(=N)c1sccc1[N+](=O)[O-])C(C)=O</smiles>

19

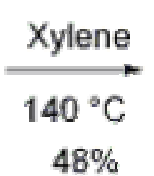

$48 \%$<smiles>COC(=O)c1nc(-c2sccc2[N+](=O)[O-])nc(O)c1O</smiles>

20

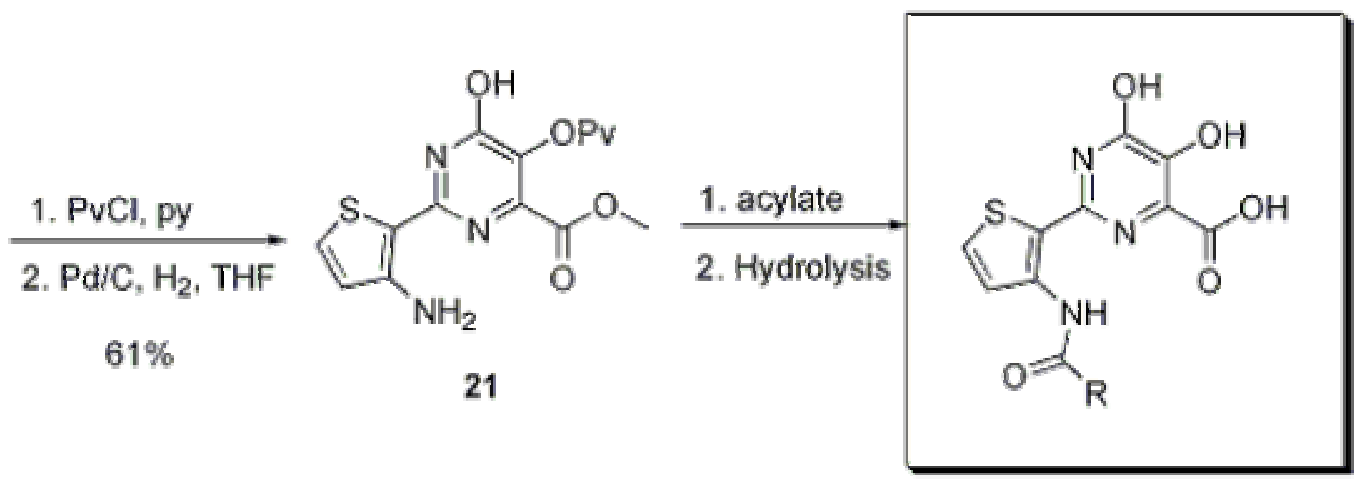

\section{Scheme 2}

From this work the benzyl urea 22 emerged as one of the most potent compounds (Figure 3). An aryl group at some distance from the thiophene further increased activity with respect to 13. It was also found that the two hydroxyl groups as well as the acid are absolutely required for activity. The urea substituent causes a significant increase in the acidity of the 5-hydroxy group ( $\mathrm{p} K_{\mathrm{a}}$ 6.6) compared to unsubstituted 13, which is somewhat unexpected since the urea is not directly attached to the pyrimidine. A possible explanation comes from modeling, which suggests a planar conformation for 22, despite the presence of a substituent in the 3-position of the thiophene. In the conformation shown in Figure 3, it is possible for the inner urea NH to form a close intramolecular contact with the $\mathrm{N} 3$ of the pyrimidine and for the outer urea $\mathrm{NH}$ a second interaction with the carboxylate is possible. These interactions would enforce a planar conformation and could help to increase the acidity of 22. An indirect proof comes from the $N$ methyl pyrimidone 23, which is one order of magnitude less potent than 22. As a consequence of the twist induced by the $N$-methyl group, the side-chain now occupies a different region of space, which explains the loss of potency. Interestingly, the $\mathrm{p} K_{\mathrm{a}}$ of $\mathbf{2 3}$ is higher compared to 22 and does not change with respect the unsubstituted $N$-methyl 2-thienyl pyrimidone 27 ( $\mathrm{p} K_{\mathrm{a}} 9.1$, see 
Figure 4), confirming the hypothesis that the formation of close intramolecular contacts between the urea $\mathrm{NH}$ and the pyrimidine helps to increase acidity.

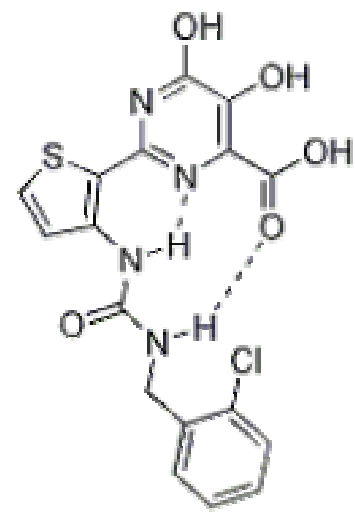

22

$\mathrm{IC}_{50} \quad 0.15 \mu \mathrm{M}$

$\mathrm{pK}$ 㱐 $(5-\mathrm{OH}) 6.6$<smiles>Cn1c(-c2sccc2NC(=O)NCc2ccccc2Cl)nc(C(=O)O)c(O)c1=O</smiles>

23

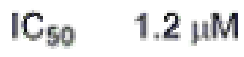

$\mathrm{p} K_{\text {a }}(5-\mathrm{OH}) 9.2$

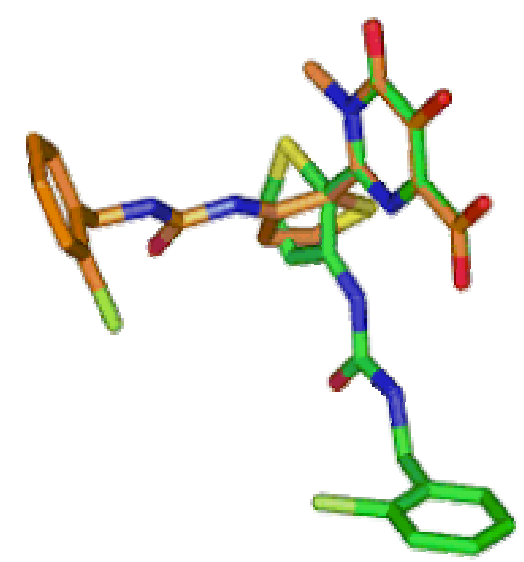

Figure 3. Structures and superposition of inhibitors 22 (green) and 23 (orange).

\section{Investigation of the dihydroxypyrimidine core}

During the development of the SAR around $\mathbf{1 3}$ we also investigated replacements of the dihydroxypyrimidine core, with the aim to replace some of the polar functionality on the pyrimidine. As the structures in Figure 4 show, this was not successful, except in the case of the $\mathrm{N}$-methylpyrimidone 27 and the pyridine- $N$-oxide 28, which showed similar potency with respect to the parent dihydroxypyrimidines $\mathbf{1 3}$ and $\mathbf{3}^{22,27}$

The initial synthesis for $\mathbf{2 7}$ and $\mathbf{2 8}$ did not allow the introduction of a wide variety of substituents, and thus limited a full exploration of the SAR. To overcome these limitations we investigated several possible routes towards these novel ketoacid replacements. 
<smiles></smiles>

$1 \mathrm{C}_{50}>100 \mu \mathrm{M}$

27<smiles>Cn1c(-c2cccs2)nc(C(=O)O)c(O)c1=O</smiles>

$1 \mathrm{C}_{50} 4.7 \mu \mathrm{M}$<smiles>O=C(O)c1c(O)c(O)nc2ccccc12</smiles>

25<smiles>O=C(O)c1nc(-c2cccs2)c2cccnc2c1O</smiles>

26
28<smiles>O=C(O)c1cc(-c2ccccc2)cn(O)c1=O</smiles>

$1 \mathrm{C}_{50} 27 \mu \mathrm{M}$

\section{Figure 4}

\subsection{N1-substituted pyrimidones}

The first approach to N1-alkylated pyrimidones relied on the alkylation of a suitably protected dihydroxypyrimidine and gave mixtures of the $\mathrm{O}$ - and $\mathrm{N}$-alkylated product. Another drawback was that the reaction worked only with reactive electrophiles, which severely limited the range of substituents we could introduce. Use of the $N$-methyl amidoxime $\mathbf{2 9}$ as a starting material solved the problem of the non-selective alkylation, as Scheme 3 shows. Reaction of $\mathbf{2 9}$ with DMAD gave the 2-methyl-1,2,4-oxadiazole $\mathbf{3 0}$ in a double Michael addition as the sole product in good yield. Heating $\mathbf{3 0}$ in xylene then produced the desired $N$-methyl pyrimidone ester $\mathbf{3 1}$ in good isolated yield, probably via opening of the oxadiazole, followed by a Claisen-type rearrangement and subsequent ring closure, as was described for the dihydroxypyrimidines (Scheme 1 ). ${ }^{28}$ 


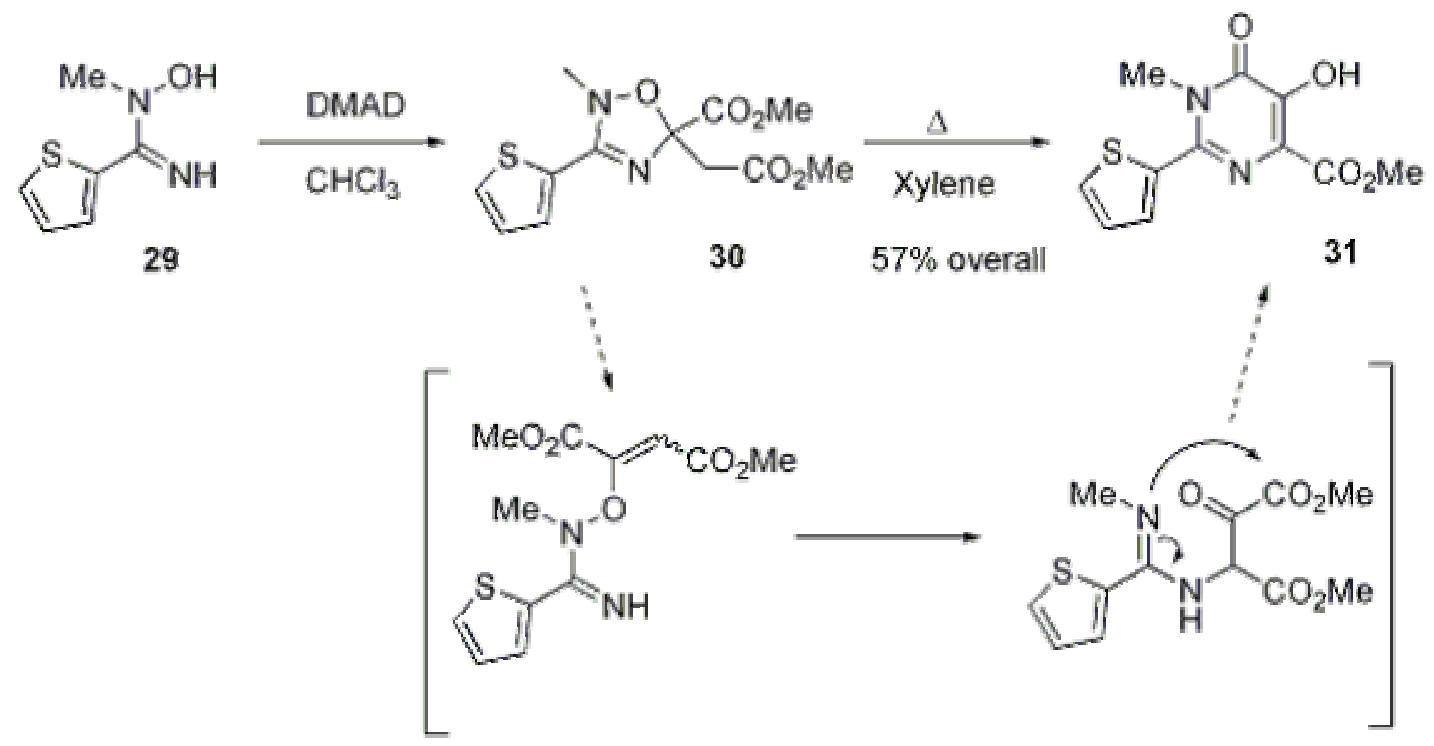

\section{Scheme 3}

Interestingly, the isomeric thiophenecarboximidamide 32 did not give the N3-methyl pyrimidone 34, but the N1-methyl pyrimidone 31 (Scheme 4). Our initial investigation of this reaction revealed that 32 on reaction with DMAD gave a mixture of the regioisomeric monoMichael adducts 33 (Scheme 4). The Z-adduct 33-Z cyclized to the 4-methyl-1,2,4-oxadiazole 35 on heating, but did not rearrange to a pyrimidone, even after prolonged heating, unlike its regioisomer 30. The E-adduct $\mathbf{3 3 - E}$ on the other hand gave rise to the N1-methyl pyrimidone 31 together with imidazole 36 . None of the $N 3$-methylpyrimidone 34 was formed, suggesting that the reaction does not proceed via a Claisen-type [3,3]-rearrangement, as it is hypothesized for the formation of dihydroxypyrimidines (Scheme 1) and $N$-alkylpyrimidones (Scheme 3). We currently think that here a [1,3]-shift is operating, which via intermediate 37 leads to the observed products 31 and $36 .^{28}$ 


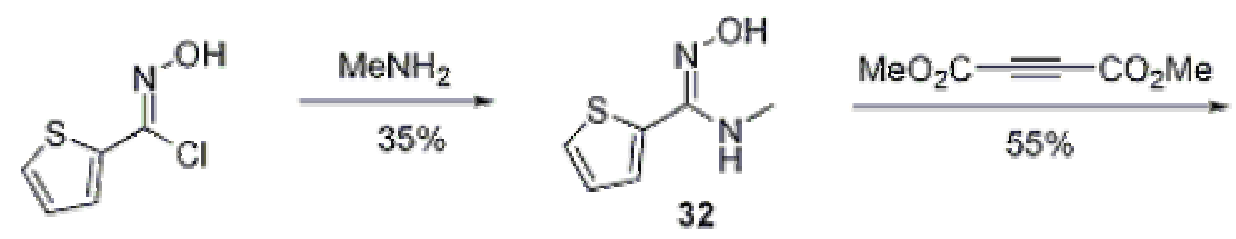<smiles>CNN/C(=N\O/C(=C/C(=O)OC)OC)c1cccs1</smiles>

$33-Z$

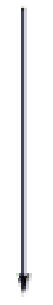<smiles>COCCC1(C(C)=O)ON=C(c2cccs2)N1C</smiles>

major product<smiles>CN/C(=N\O/C(=C/C(C)=O)C(C)=O)c1cccs1</smiles>

33-E $(1: 4)$<smiles>CC(=O)c1c(O)c(=O)nc(-c2ccc(C(C)(C)C)s2)n1C</smiles>

34

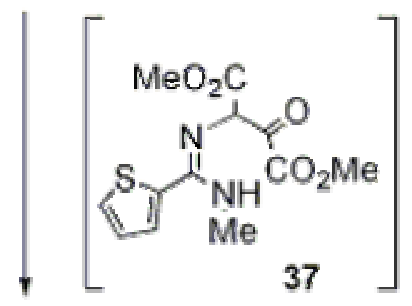<smiles>O=C(O)c1nc(-c2cccs2)n(CC(F)(F)F)c(=O)c1O</smiles>

38<smiles>COC(=O)c1nc(-c2cccs2)n(C)c(=O)c1O</smiles>

$28 \%$

$25 \%$

36<smiles>O=C(O)c1nc(-c2cccs2)n(CCc2ccccc2Cl)c(=O)c1O</smiles>

\section{Scheme 4}

Although the overall yield for this process was low, we were able to obtain products such as 38 and 39, which were not accessible by the alkylation methodology. A drawback of the approaches described in Schemes 3 and 4 is that both the $N 1$ - and the 2-substituent have to be introduced in the first steps of the synthesis.

Recently we developed a novel approach, relying on palladium catalyzed cross-coupling for the carbon-carbon-bond formation in the 2-position and avoiding the non-selective N1functionalization. ${ }^{29}$ This method is virtually unprecedented in the literature and judging from the first results seems to be quite versatile (Scheme 5). 


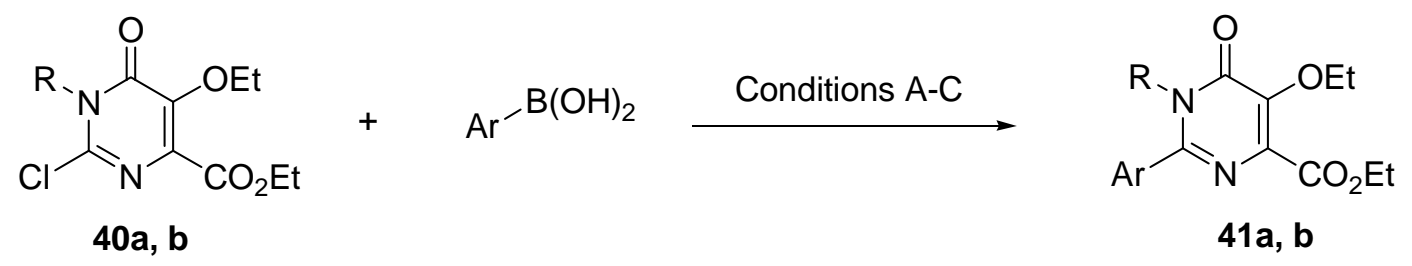

Thermal

A $6 \% \mathrm{Pd}_{2} \mathrm{dba}_{3}, 12 \%\left[\left({ }^{\mathrm{t}} \mathrm{Bu}\right)_{3} \mathrm{PH}\right] \mathrm{BF}_{4}$, $\mathrm{KF}$, dioxane, $135^{\circ} \mathrm{C}, 16 \mathrm{~h}$

\section{Microwave}

B $6 \% \mathrm{Pd}_{2} \mathrm{dba}_{3}, 12 \%\left[\left({ }^{\mathrm{t}} \mathrm{Bu}\right)_{3} \mathrm{PH}\right] \mathrm{BF}_{4}$,

$\mathrm{KF}$, dioxane, $135^{\circ} \mathrm{C}, 10-20 \mathrm{~min}$

C $10 \% \mathrm{Pd}\left(\mathrm{PPh}_{3}\right)_{4}, \mathrm{~K}_{3} \mathrm{PO}_{4}$ toluene/DMF (5:1), $200{ }^{\circ} \mathrm{C}, 5 \mathrm{~min}$
$41 \mathrm{a} R=\mathrm{Me}$<smiles>COc1ccccc1</smiles>

A $86 \%$

C $88 \%$<smiles>OC=Cc1ccccc1</smiles>

B $70 \%$<smiles>COc1ccccc1C</smiles>

A $0 \%$

B $77 \%$<smiles>Oc1cccc2ccccc12</smiles>

A $15 \%$
C $81 \%$<smiles></smiles>

A $99 \%$

41b $\mathrm{R}=\mathrm{Ph}$<smiles>COc1ccccc1</smiles>

B $84 \%$<smiles>COc1ccccc1C</smiles>

B $34 \%$

C $74 \%$

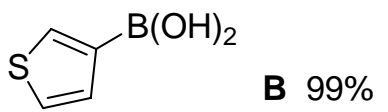

Cul, NEt 3 , THF, $\mathrm{Pd}\left(\mathrm{PPh}_{3}\right)_{2} \mathrm{Cl}_{2}$ 42 $64 \%$

Scheme 5. Carbon-carbon bond formation in the 2-position of N1-substituted pyrimidones

2-Chloro-1-substituted pyrimidones 40, which are available in multi-gram quantities undergo Suzuki or Sonogashira reactions using standard coupling protocols. The $N$-Methyl derivative 40a for example gives good yields in the cross-coupling with most boronic acids under thermal conditions. Increased steric demand on the boronic acid partner led to low yields or no coupling product, as is shown for the case of the $o$-tolyl derivative. In this case microwave irradiation promoted coupling in good yield. The $N$-phenyl pyrimidone $40 \mathrm{~b}$ reacted only under microwave irradiation. Proper choice of catalyst and irradiation time allowed also the coupling of the sterically hindered $o$-tolyl boronic acid.

The acetylene 42 was obtained under standard Sonogashira coupling conditions. 


\subsection{Pyridine- $N$-oxides}

The initial synthesis of pyridine- $N$-oxide $\mathbf{2 8}$ relied on the oxidation of the pyridine to its $N$-oxide in the late stage of the synthesis. This step was low yielding, and moreover the product was difficult to separate from the starting pyridine. The harsh reaction conditions would also not compatible with sensitive functionality. We envisioned a milder way, relying on a $[3+2+1]$ annulation strategy recently published by the Merck process group. ${ }^{30,31}$ Here a vinamidinium salt 44 is reacted with the $\beta$-ketoester $\mathbf{4 3}$ and hydroxylamine in the presence of two bases to give directly pyridine- $N$-oxide 45. Mechanistic investigations confirmed that 46 and 47 are intermediates in this process. ${ }^{31}$

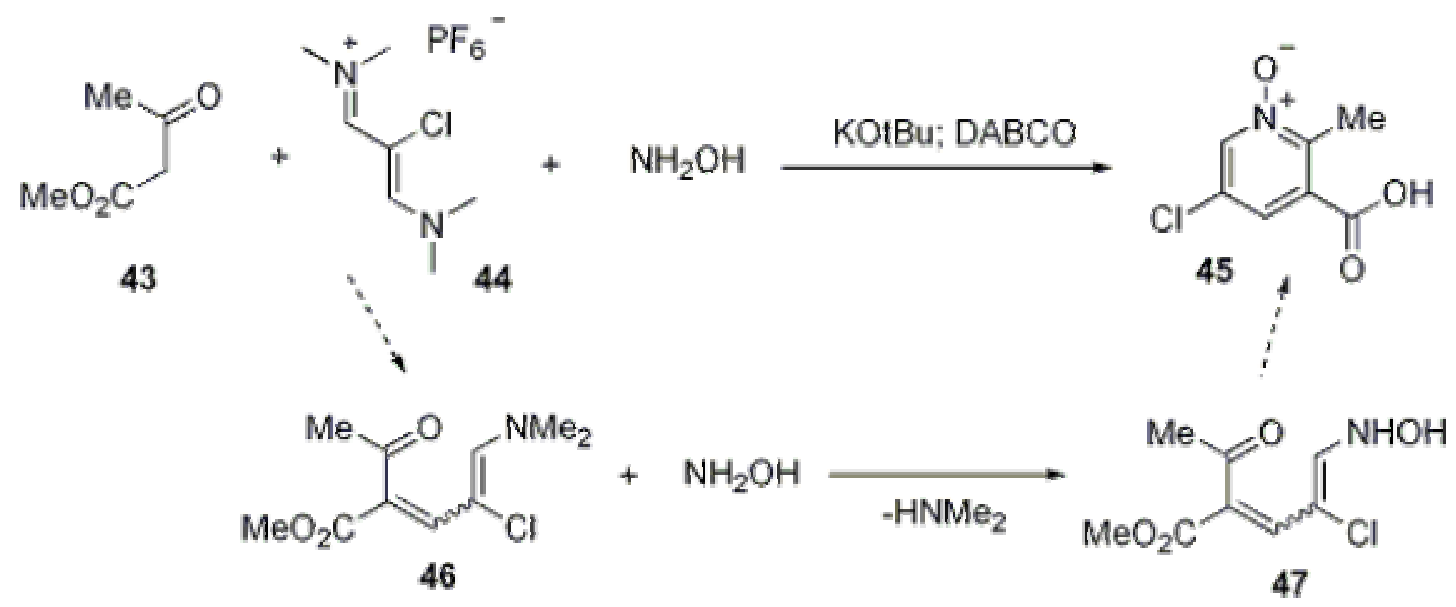

\section{Scheme 6}

Using the published conditions and several variations thereof, we were unable to bring about the reaction of malonate-derived 48 to $N$-oxide 50. A possible explanation could be the lower reactivity of the ester group in $\mathbf{4 9}$ compared to the ketone in $\mathbf{4 7}$ in the final cyclization step. It was not really clear however, if $\mathbf{4 9}$ was formed at all from $\mathbf{4 8}$ and hydroxylamine, since the reaction mixtures became difficult to analyze after prolonged reaction time. We hypothesized that by bringing in the hydroxylamine from the beginning, thus using a [3+3] annulation instead of the $[3+2+1]$, might circumvent this problem. As it turned out, when the 3[(benzyloxy)amino]-3-oxopropanoate 51 was prepared and reacted with $\mathbf{4 4}$ at room temperature in THF, the protected $N$-oxide $\mathbf{5 3}$ was obtained in good isolated yield. ${ }^{32}$ 
<smiles>CCOC(=O)C(=CC(Cl)=CNO)C(=O)OCC</smiles>

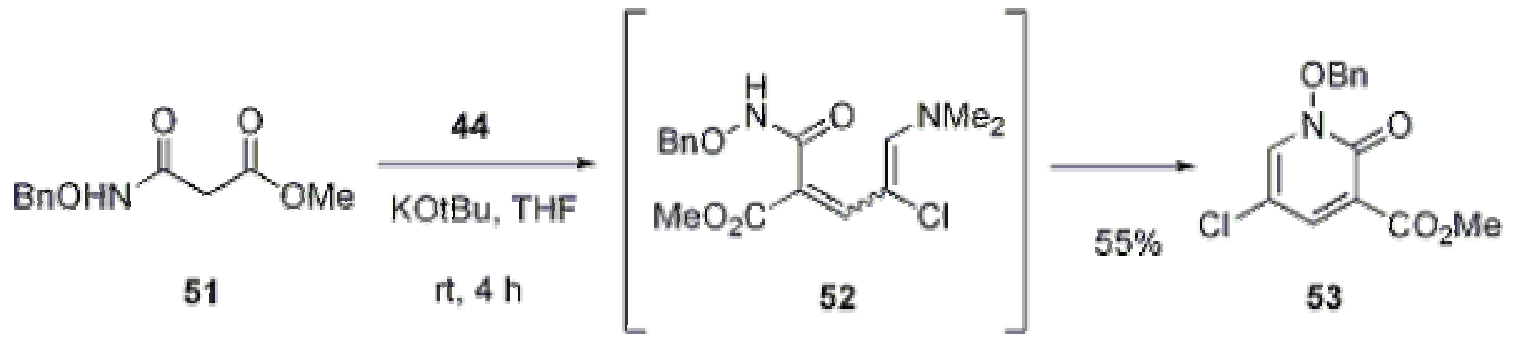

\section{Scheme 7}

Unfortunately, chloride in $\mathbf{5 3}$ did not undergo Suzuki or Stille-type cross-coupling conditions under a variety of conditions, so we resorted to the preparation of aryl-vinamidinium salts such as 54. Also these reacted smoothly with $\mathbf{5 1}$ to give the desired product 55. Further investigations in this area are on-going.<smiles>COC(=O)CC(=O)NOCc1ccccc1</smiles>

\section{Scheme 8}

\section{Conclusions}

By investigating the SAR of dihydroxypyrimidine 3 in the 2-position, we identified several groups that led to a 10-40-fold gain in potency. Further SAR around the 2-thienyl analog 13 then led to inhibitors like 22, which had sub-micromolar affinity on the NS5B polymerase. During this work we were able to identify the factors which contribute to binding of the pyrimidines to the HCV NS5B polymerase. Modulation of the $\mathrm{p} K_{\mathrm{a}}$ by substituents in the 2-position of the 
pyrimidine influences affinity by their effect on Mg-chelation. A substituent in the 3-position of the thiophene terminating with a lipophilic aryl residue leads to a further increase in potency. The urea group enforces a planar arrangement of the pyrimidine, as suggested by modeling, and due to a hydrogen-bonding network further increases the acidity of the 5-hydroxy group.

SAR around the pyrimidine scaffold led to the discovery of $N 1$-substituted pyrimidones and pyridine- $N$-oxides. The work on the former offered some insight into the rearrangement mechanism of the Michael adducts, which are intermediates in the formation of dihydroxypyrimidines and pyrimidones. Different mechanisms might be operating for different series, but a thorough investigation of the reaction mechanism is needed.

A robust methodology relying on palladium mediated coupling was subsequently developed for the carbon-carbon-bond formation in N1-substituted pyrimidones. This methodology has the potential to give access to a broad variety of substitution patterns in this position. For the pyridine- $N$-oxides a novel and mild cyclization strategy was found, which allowed access to the desired target molecules.

\section{Acknowledgements}

We thank Silvia Pesci for NMR experiments and to Francesca Naimo and Anna Alfieri for analytical chemistry. We are grateful to Nadia Gennari, Monica Bisbocci, Sergio Serafini and Mauro Cerretani for the inhibition data on the NS5B enzyme. This work was supported in part by a grant from the MIUR.

\section{References and Notes}

1. Wasley, A.; Alter, M. J. Semin Liver Dis 2000, 20, 1-16.

2. Lauer, G. M.; Walker, B. D. N. Engl. J. Med. 2001, 345, 41-52.

3. McHutchison, J. G. Am. J. Manag. Care 2004, 10, S21-9.

4. McHutchison, J. G.; Manns, M.; Patel, K.; Poynard, T.; Lindsay, K. L.; Trepo, C.; Dienstag, J.; Lee, W. M.; Mak, C.; Garaud, J. J.; Albrecht, J. K. Gastroenterology 2002, 123, 10611069.

5. Tan, S. L.; Pause, A.; Shi, Y.; Sonenberg, N. Nat. Rev. Drug Discov. 2002, 1, 867-81.

6. Gordon, C. P.; Keller, P. A. J. Med. Chem. 2005, 48, 1-20.

7. De Francesco, R.; Migliaccio, G. Nature 2005, 436, 953-960.

8. Lahm, A.; Yagnik, A.; Tramontano, A.; Koch, U. Curr. Drug Targets 2002, 3, 281-96.

9. Wang, Q. M.; Hockman, M. A.; Staschke, K.; Johnson, R. B.; Case, K. A.; Lu, J.; Parsons, S.; Zhang, F.; Rathnachalam, R.; Kirkegaard, K.; Colacino, J. M. In J. Virol. 2002; Vol. 76, p 3865-3872. 
10. Love, R. A.; Parge, H. E.; Yu, X.; Hickey, M. J.; Diehl, W.; Gao, J.; Wriggers, H.; Ekker, A.; Wang, L.; Thomson, J. A.; Dragovich, P. S.; Fuhrman, S. A. J. Virol. 2003, 77, 7575-81.

11. Biswal, B. K.; Cherney, M. M.; Wang, M.; Chan, L.; Yannopoulos, C. G.; Bilimoria, D.; Nicolas, O.; Bedard, J.; James, M. N. J. Biol. Chem. 2005, 280, 18202-10.

12. Di Marco, S.; Volpari, C.; Tomei, L.; Altamura, S.; Harper, S.; Narjes, F.; Koch, U.; Rowley, M.; De Francesco, R.; Migliaccio, G.; Carfi, A. J. Biol. Chem. 2005, 280, 2976529770.

13. Harper, S.; Avolio, S.; Pacini, B.; Di Filippo, M.; Altamura, S.; Tomei, L.; Paonessa, G.; Di Marco, S.; Carfi, A.; Giuliano, C.; Padron, J.; Bonelli, F.; Migliaccio, G.; De Francesco, R.; Laufer, R.; Rowley, M.; Narjes, F. J. Med. Chem. 2005, 48, 4547-57.

14. Beaulieu, P. L.; Tsantrizos, Y. S. Curr. Opin. Investig. Drugs 2004, 5, 838-850.

15. Condon, S. M.; LaPorte, M. G.; Herbertz, T. Curr. Med. Chem.: Anti-Infective Agents 2005, 4, 99-110.

16. Eldrup, A. B.; Allerson, C. R.; Bennett, C. F.; Bera, S.; Bhat, B.; Bhat, N.; Bosserman, M. R.; Brooks, J.; Burlein, C.; Carroll, S. S.; Cook, P. D.; Getty, K. L.; MacCoss, M.; McMasters, D. R.; Olsen, D. B.; Prakash, T. P.; Prhavc, M.; Song, Q.; Tomassini, J. E.; Xia, J. J. Med. Chem. 2004, 47, 2283-95.

17. Summa, V.; Petrocchi, A.; Pace, P.; Matassa, V. G.; De Francesco, R.; Altamura, S.; Tomei, L.; Koch, U.; Neuner, P. J. Med. Chem. 2004, 47, $14-7$.

18. Grobler, J. A.; Stillmock, K.; Hu, B.; Witmer, M.; Felock, P.; Espeseth, A. S.; Wolfe, A.; Egbertson, M.; Bourgeois, M.; Melamed, J.; Wai, J. S.; Young, S.; Vacca, J.; Hazuda, D. J. Proc. Natl. Acad. Sci. U. S. A. 2002, 99, 6661-6.

19. De Clercq, E. J. Clin. Virol. 2004, 30, 115-133.

20. Pace, P.; Nizi, E.; Pacini, B.; Pesci, S.; Matassa, V.; De Francesco, R.; Altamura, S.; Summa, V. Bioorg. Med. Chem. Lett. 2004, 14, 3257-61.

21. Summa, V.; Petrocchi, A.; Matassa, V. G.; Taliani, M.; Laufer, R.; De Francesco, R.; Altamura, S.; Pace, P. J. Med. Chem. 2004, 47, 5336-9.

22. Stansfield, I.; Avolio, S.; Colarusso, S.; Gennari, N.; Narjes, F.; Pacini, B.; Ponzi, S.; Harper, S. Bioorg. Med. Chem. Lett. 2004, 14, 5085-8.

23. Crescenzi, B.; Poma, M.; Ontoria, J. M.; Marchetti, A.; Nizi, E.; Matassa, V. G.; Gardelli, C. Letters in Drug Design \& Discovery 2005, 2, 451-455.

24. Ponzi, S.; Giuliano, C.; Donghi, M.; Poma, M.; Matassa, V. G.; Stansfield, I. Letters in Drug Design \& Discovery 2005, 2, 456-461.

25. Culbertson, T. P. J. Heterocycl. Chem. 1979, 16, 1423-4.

26. Koch, U.; Attenni, B.; Malancona, S.; Colarusso, S.; Conte, I.; Di Filippo, M.; Harper, S.; Pacini, B.; Giomini, C.; Thomas, S.; Incitti, I.; Tomei, L.; De Francesco, R.; Altamura, S.; Matassa, V. G.; Narjes, F. J. Med. Chem. 2006, 49, 1693-1705.

27. Colarusso, S.; Narjes, F., unpublished results. 
28. Avolio, S.; Colarusso, S.; Conte, I.; Harper, S.; Koch, U.; Malancona, S.; Matassa, V. G.; Narjes, F.; Petrocchi, A.; Summa, V. In PCT Int. Appl.; (Istituto Di Ricerche Di Biologia Molecolare P. Angeletti Spa, Italy). WO 2003/062211.

29. Colarusso, S.; Girardin, M.; Conte, I.; Narjes, F. Synthesis 2006, in press.

30. Davies, I. W.; Marcoux, J. F.; Reider, P. J. Organic Letters, 3, 209-11.

31. Marcoux, J. F.; Marcotte, F. A.; Wu, J.; Dormer, P. G.; Davies, I. W.; Hughes, D.; Reider, P. J. J. Org. Chem., 66, 4194-9.

32. Colarusso, S.; Narjes, F. PCT Int. Appl.; (Istituto di Ricerche di Biologia Molecolare P. Angeletti S.p.A., Italy). WO 2004/110442. 